\title{
A COMPARATIVE STUDY ON THE FEEDING COMPETITION OF THE EUROPEAN PERCH PERCA FLUVIATILIS L. AND THE RUFFE GYMNOCEPHALUS CERNUUS (L.) IN LAKE PIEDILUCO (UMBRIA, ITALY).
}

\author{
M. LORENZONI, A. CAROSI, G. PEDICILLO, A. TRUSSO
}

Dipartimento di Biologia Cellulare e Ambientale - Sezione di Biologia Animale ed Ecologia - Università di Perugia, Via Pascoli, 06100 Perugia Italy.

corresponding author: lorenzon@unipg.it

Reçu le 8 février 2007

Accepté le 17 décembre 2007

Received February 8, 2007

Accepted December 17, 2007

\section{ABSTRACT}

The abundance of European perch in Lake Piediluco has significantly dwindled in the last few years. The present study on diet overlap between perch and ruffe was prompted by the rapid expansion of the ruffe stock in the lake. This species was first found in the lake in 1996 and has since become one of the most abundant. The degree of diet overlap between the two species was analyzed by using data on the stomach contents of 275 European perch and 328 ruffe. Results are expressed as abundance $(\% \mathrm{~N})$, occurrence $(\% \mathrm{~S})$, weight percentage $(\% \mathrm{~W})$ and index of predominance $\left(\mathrm{I}_{\mathrm{p}}\right)$. The diet overlap index $(\alpha)$ was calculated by means of Schoener's formula using the \%W of each food item. As an estimate of the diet width of both species, we used Levins' indexes of niche breadth $(B)$ and standardized measurement of niche breadth $\left(B_{A}\right)$. Both species are strictly carnivorous, feeding mainly on invertebrates: the most important diet components were dipterans and crustaceans, but the European perch also feeds on fish. In the perch, the Levins index was greater $(B=4.332)$ than that calculated for the ruffe $(B=2.262)$. During the ontogenesis of the European perch, there is a rather pronounced diet shift: dipterans form the largest portion of the diet at all ages, though in older perch fish-eating becomes increasingly evident. Benthic crustaceans tend to be consumed in greater quantities by the $3+$ age-class, though they are also found in the stomachs of specimens of all ages. Ruffe, by contrast, do not display a pronounced ontogenetic diet shift.

The index of diet overlap between the two species was rather high, the maximum $\alpha$ value being 0.853 ; values indicate a high degree of diet overlap in the younger ageclasses $(1+, 2+$ and $3+)$, with a greater differentiation between the diets of the two species emerging as the age of the perch increased.

Our research also clarified some of the biological characteristics of the European perch in Lake Piediluco, namely, theoretical growth in length, weight at length and relative weight. These analyses enabled us to compare the growth characteristics of the European perch during periods when ruffe stocks differed in terms of abundance. All of the results indicate that the growth conditions of the European perch population in Lake Piediluco are steadily worsening. This provides indirect confirmation of a negative interaction with the ruffe.

Key-words: diet overlap, food, growth, relative weight. 


\section{ÉTUDE COMPARATIVE DE LA COMPÉTITION ALIMENTAIRE ENTRE LA PERCHE COMMUNE PERCA FLUVIATILIS L. ET LA GRÉMILLE GYMNOCEPHALUS CERNUUS (L.) DANS LE LAC DE PIEDILUCO (OMBRIE, ITALIE).}

\section{RÉSUMÉ}

Durant les dernières années, le nombre de perches communes présentes dans le lac de Piediluco a sensiblement décru. La présente étude concernant le chevauchement alimentaire entre la perche et la grémille a été motivée par l'expansion rapide de l'effectif des grémilles dans le lac. Cette espèce a été repérée pour la première fois dans le lac en 1996 et est aujourd'hui l'une des espèces les plus abondantes. Le degré de chevauchement alimentaire entre les deux espèces a été analysé en utilisant des données sur le contenu de l'estomac de 275 perches communes et de 328 grémilles. Les résultats sont exprimés en abondance $(\% \mathrm{~N})$, occurrence $(\% \mathrm{~S})$, pourcentage de poids $(\% \mathrm{~W})$ et indice de prépondérance $\left(I_{p}\right)$. L'indice de chevauchement alimentaire $(\alpha)$ a été calculé d'après la formule de Schoener, de deux manières, en utilisant les pourcentages d'abondance $(\% \mathrm{~N})$ et de poids $(\% \mathrm{~W})$ de chaque aliment. Pour évaluer l'amplitude du régime alimentaire des deux espèces, nous avons utilisé les indices de Levins d'étendue de niche (B) et les mesures standard d'étendue de niche $\left(B_{A}\right)$. Les deux espèces sont strictement carnivores et se nourrissent essentiellement d'invertébrés: les principaux composants de leur régime alimentaire sont les diptères et les crustacés, mais la perche commune se nourrit également de poisson. Chez la perche commune, l'indice de Levins est supérieur $(B=4,332)$ à celui qui a été calculé pour la grémille $(B=2,262)$. Durant l'ontogenèse de la perche commune, on constate une variation relativement prononcée du régime alimentaire: les diptères constituent la plus grande part de son régime alimentaire à tous les âges, tandis que la consommation de poisson devient de plus en plus prononcée chez la perche plus âgée. Les crustacés benthiques tendent à être consommés en plus grande quantité par les poissons d'âge moyen ( $3+$ ), bien qu'on en ait trouvé dans l'estomac de spécimens de tous les âges. Inversement, le régime ontogénétique de la grémille ne révèle pas de variation prononcée.

L'indice de chevauchement alimentaire entre les régimes des deux espèces est relativement élevé: la valeur $\alpha$ maximum étant 0.853; en général les valeurs indiquent la présence d'un chevauchement alimentaire élevé dans les régimes alimentaires des classes d'âge plus jeunes $(1+, 2+, 3+)$, avec une tendance à une plus grande différenciation des spectres alimentaires entre les deux espèces à mesure que l'âge de la perche commune augmente.

Notre recherche a également précisé certaines caractéristiques biologiques de la perche commune du lac de Piediluco, en particulier la croissance théorique en longueur, le poids en fonction de la longueur et le poids relatif. Ces analyses ont permis de comparer entre elles les caractéristiques de la croissance de la perche commune à des périodes où la grémille était plus ou moins abondante. Tous les résultats semblent indiquer que les conditions de croissance de la population de la perche commune du lac de Piediluco empirent progressivement avec le temps. Ceci peut confirmer indirectement une forte interaction négative avec la grémille.

Mots-clés: recoupement alimentaire, aliment, croissance, poids relatif.

\section{INTRODUCTION}

The composition of the fish fauna of Lake Piediluco has undergone significant changes in recent years, mainly because of environmental deterioration due to the eutrophication of the lake and the introduction of some non-native species in the past. 
The original species found in the lake are: pike Esox lucius L., 1758, rudd Scardinius erythrophthalmus (Linnaeus, 1758), three-spined stickleback Gasterosteus aculeatus Linnaeus, 1758, Italian roach Rutilus rubilio (Bonaparte, 1837), tench Tinca tinca (Linnaeus, 1758), eel Anguilla anguilla (Linnaeus, 1758), brown trout Salmo trutta Linnaeus, 1758 and chub Leuciscus cephalus (Linnaeus, 1758). In the 1920s, in order to sustain commercial fishing, perch Perca fluviatilis Linnaeus, 1758 and whitefish Coregonus lavaretus (Linnaeus, 1758) (RICCARDI, 1955) were introduced; these species acclimatised and reproduced so rapidly that they soon became the principal commercial species in the lake (GIOVINAZZO, 1988). In the 1960s, other exotic species were accidentally introduced; these included the northern Italian roach Rutilus aula (Bonaparte, 1841), the pumpkinseed Lepomis gibbosus (Linnaeus, 1758) and the Italian bleak Alburnus alburnus alborella (De Filippi, 1844), which subsequently became particularly abundant.

These modifications have led to a decrease in fishery yields; owing to the drastic reduction in catches, the local fishermen's cooperative suspended its activity in 2002. The local populations of three-spined stickleback and Italian roach have died out, the latter probably as a result of competition with the northern Italian roach (LORENZONI et al., 2006). The European perch population of Lake Piediluco has declined dramatically; environmental deterioration caused by eutrophication of the lake (MEARELLI, 1988) and the introduction of exotic fish species that are potential competitors of the European perch (PACE et al., 2006) are probably the most important factors that have contributed to this situation. With regard to its trophic condition, Lake Piediluco has undergone a rapid evolution, caused mainly by an increase in nutrients from its drainage basin.

The ruffe Gymnocephalus cernuus (Linnaeus, 1758) is one of the latest species to be introduced into Lake Piediluco: its presence was first recorded in 1996 (CAROSI et al., 1998) and it has acclimatized so well that it is today one of the most abundant species in the lake. In 2004, the roach Rutilus rutilus (Linnaeus, 1758) was found for the first time in the lake (LORENZONI et al., 2005).

The ruffe's highly invasive character is determined by several features: its high level of fecundity, tolerance of variations in temperature and salinity, and its capacity to feed even at low temperatures and when visibility is poor or nil (BERGMAN, 1988; JANSSEN, 1997). Wherever ruffe have become established as an exotic species, changes in the structure of fish communities have been observed (MILLS et al., 1994; ADAMS and MAITLAND, 1998); these are probably caused by competitive interactions (DIETERICH et al., 2004) or predation on eggs and larvae (ADAMS and TIPPET, 1991; KANGUR et al., 1999). In Europe (BERGMAN 1988; BERGMAN and GREENBERG, 1994; SCHLEUTER and ECKMANN, 2007) and in North America (OGLE et al., 1995; FULLERTON et al., 1998) a reduction in the abundance of perch and yellow perch Perca flavescens (Mitchill, 1814) has been observed following the introduction of the ruffe.

The diets of the ruffe (HOLKER and HAMMER, 1994; OGLE, 1998; KANGUR et al., 1999) and the European perch (THORPE, 1977; HORPPILA et al., 2000; DORNER et al., 2003) have been amply described in the literature, and numerous studies have shed light on various aspects of the interaction between these two species (BERGMAN,1991; ECKMANN, 2004; SCHLEUTER and ECKMANN, 2007). It is also known, however, that the diet range of these species displays high variability, which often proves to be linked to the specific features of the water body examined (BERGMAN, 1988; DIETERICH et al., 2004).

The aim of this study was to investigate the specific example of Lake Piediluco, a eutrophic environment in which contact between the two species is very recent. The specific objectives of this study were to characterize the diets of two important members of the fish community of Lake Piediluco, explore age-related diet similarities between these species, and illustrate diet variations between species and age-classes. In addition 
we analysed the impact of ruffe on the growth of perch by analysing some aspects of the growth of the European perch, with a view to comparing periods when the abundance of the ruffe displayed variations, while steadily increasing.

\section{MATERIAL AND METHODS}

\section{Study area}

The investigation was carried out in Lake Piediluco (longitude: $0^{\circ} 17^{\prime} 21^{\prime \prime}-0^{\circ}$ 19'17' E; latitude: $42^{\circ} 30^{\prime} 54^{\prime \prime}-42^{\circ} 32^{\prime} 28^{\prime \prime} \mathrm{N}$ ), about $20 \mathrm{~km}$ SE of Terni in Central Italy, at $368 \mathrm{~m}$ above sea level (Figure 1). With a surface area of $1.67 \mathrm{~km}^{2}$, this lake (mean depth=10.90 m; max. depth=21.48 m) (MEARELLI, 1988) is the second largest natural lake in the Umbria Region. Lake Piediluco is a regulated lake, and is used as a daily water storage basin for the Galleto hydroelectric plant. It is a hydraulic complex made up of two waterways: the Velino River and the Medio-Nera channel, which is derived from the Nera River. The hydroelectric use imposes a particular hydraulic regime: the Nera River is the main tributary flowing into the lake, while the Velino River is intermittently used as an effluent and tributary. Field measurements have shown that Lake Piediluco currently is highly eutrophic (maximum chlorophyll values: $250 \mu \mathrm{g} \mathrm{I}^{-1}$; lowest dissolved oxygen concentration: $<2 \mathrm{mg} \mathrm{l}^{-1}$ at the bottom; highest orthophosphate concentration values: 10-25 $\left.\mu \mathrm{g} \mathrm{I}^{-1}\right)(\mathrm{ClOFFI}$ and GALLERANO, 2000). In this regard, the lake's trophic evolution has been rapid, mainly on account of an increased inflow of nutrients from its drainage basin. Data regarding concentrations of total phosphorus reveal that the lake was classified as mesotrophic in $1980\left(40 \mathrm{~g} \mathrm{I} \mathrm{I}^{-1}\right)$, eutrophic in $1989\left(80 \mathrm{\mu g} \mathrm{I}^{-1}\right)$ and hypertrophic in 1994 $\left(110 \mu \mathrm{g} \mathrm{I}^{-1}\right)$ (MEARELLI, 1988; CIOFFI and GALLERANO, 2000).

\section{Fish community composition}

On the basis of the data on catches recorded by the local fishermen's cooperative, the annual yield in Lake Piediluco in 1988 was estimated to be $143 \mathrm{~kg} \mathrm{ha}^{-1}$ and was made up of European perch ( $43 \%$ of the catch), eel (33\%), pike (8\%), whitefish (8\%), tench (4\%) and other cyprinids (4\%). In 1993, the annual yield decreased to only $0.51 \mathrm{~kg} \mathrm{ha}^{-1}$. Rudd (20\% of the catch), northern Italian roach (13\%) and other less valuable species for fisheries such as Italian bleak (14\%) increased concomitantly with the eutrophication of the lake, while all the commercial species decreased: perch (10\%), eel (19\%), pike (6\%), whitefish (1\%) (BISONNI, unpublished data). In 1996, the European perch was affected by aeromonosis, a pathology caused by Aeromonas hydrophila. This bacterium develops mostly in conditions of rich organic material (WAHLI et al., 2005) and its spread in Lake Piediluco was undoubtedly favoured by the worsening condition of the lake's water. No commercial perch catches have been taken from Lake Piediluco since 2002, when the local fishermen's cooperative suspended its operations; moreover, since 1979 a programme to support the reproduction of this species has been in force.

Nevertheless, the perch population does not seem to be able to recover its former abundance. In the periods 1996, 1999 and 2005, seasonal sampling campaigns were conducted by means of gill-nets and fyke-nets, in order to investigate the overall composition of the fish community living in Lake Piediluco. Gill-nets were composed of four panels of $20,28,30,45 \mathrm{~mm}$ bar mesh size (total net area about $762.5 \mathrm{~m}^{2}$ ). The panels were arranged in series, according to increasing mesh size and were set at 6 sampling stations near the shore of the lake (Figure 1). In 1996, perch accounted for $26.49 \%$ of catches and $11.47 \%$ of the biomass, while in 2005 these values were $11.61 \%$ and $5.32 \%$,

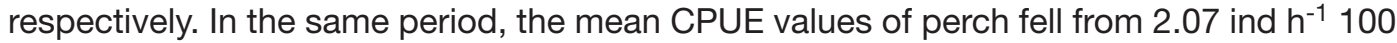
$\mathrm{m}^{-2}$ to 1.31 ind $\mathrm{h}^{-1} 100 \mathrm{~m}^{-2}$ for gill-nets and from $0.12 \mathrm{ind} \mathrm{h}^{-1}$ to $0.073 \mathrm{ind} \mathrm{h}^{-1}$ for fyke-nets (LORENZONI et al, 2005). 


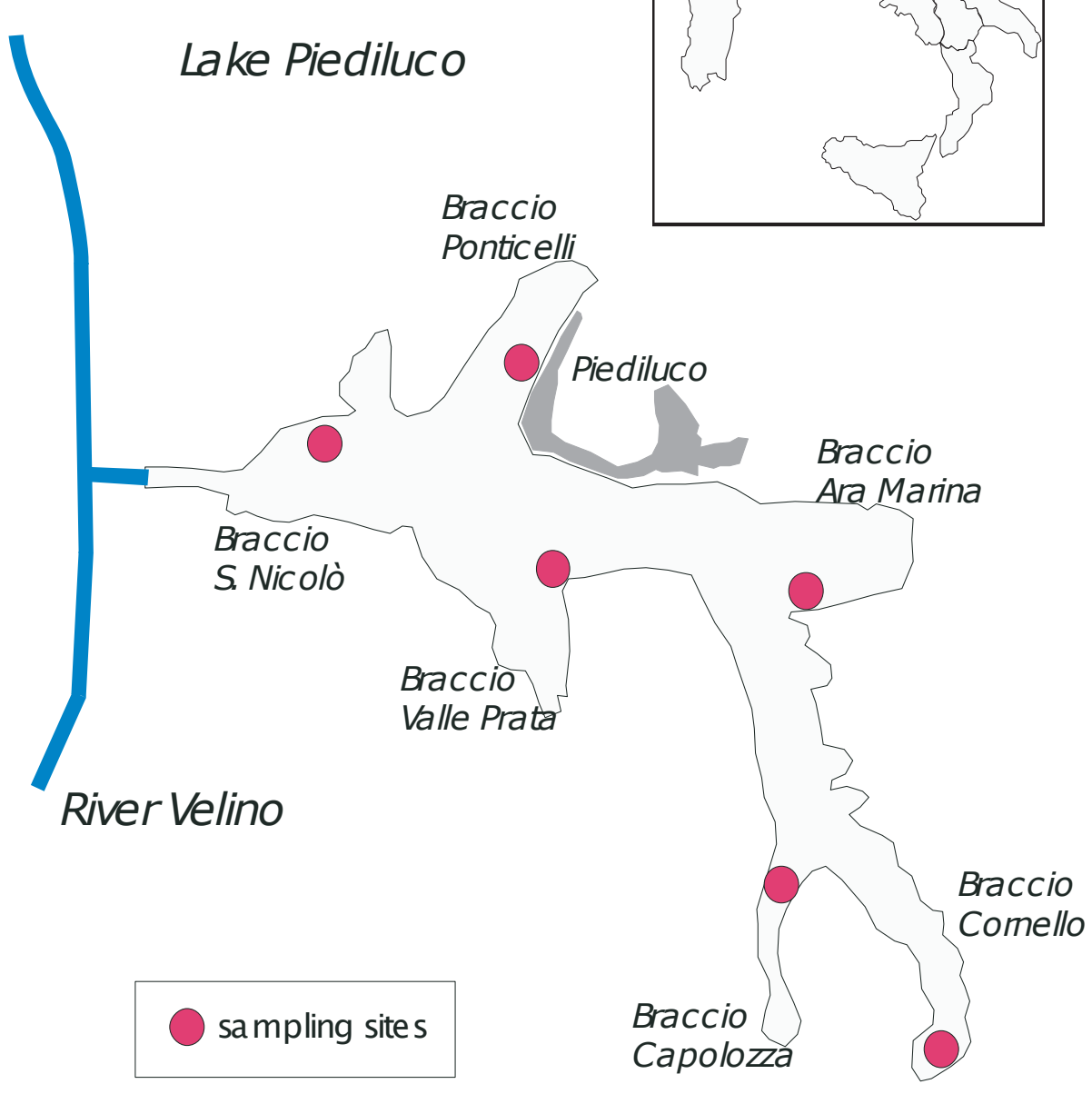

\section{Figure 1}

Lake Piediluco, Italy. Investigated area and sampling sites.

\section{Figure 1}

Lac de Piediluco, Italie. Domaine de la recherche et sites d'échantillonnage. 
Simultaneous to the decline of the perch population in the lake, an increase in the abundance of some cyprinids and the ruffe was recorded. The mean CPUEs of northern Italian roach caught by gill-nets were 0.54 ind h$^{-1} 100 \mathrm{~m}^{-2}$ in 1996 and 1.36 ind h$^{-1} 100 \mathrm{~m}^{-2}$ in 2005. The roach, which was absent in 1999, reached a mean value of $0.93 \mathrm{ind} \mathrm{h}^{-1} 100 \mathrm{~m}^{-}$ 2 in 2005. The rudd is one of the native species that have benefited most from the changes that have taken place in the lake: the mean CPUEs for gill-nets were $1.36 \mathrm{ind} \mathrm{h}^{-1} 100 \mathrm{~m}^{-2}$ and 1.49 ind $\mathrm{h}^{-1} 100 \mathrm{~m}^{-2}$ in 1996 and 2005, respectively (LORENZONI et al., 2005). In the last few years, the abundances of ruffe increased steadily; caught for the first time in 1996 (CAROSI et al., 1998), by 1999 it accounted for $1.90 \%$ of catches and $0.40 \%$ of the biomass, and by 2005 these percentages had risen to $20.95 \%$ and $4.99 \%$, respectively (LORENZONI et al., 2005). In the same period, the mean CPUE values of gill-net catches rose from 0.12 ind $\mathrm{h}^{-1} 100 \mathrm{~m}^{-2}$ to 2.32 ind $\mathrm{h}^{-1} 100 \mathrm{~m}^{-2}$.

\section{Diet analysis}

For diet analysis, ruffe were collected seasonally between June 1999 and March 2002, while perch sampling was conducted seasonally between May 2000 and May 2003. The nets were positioned along the entire shore line of the lake for one night. Both species proved to be present in all locations and did not display particular preferences (LORENZONI et al., 2005).

All specimens of both species were weighed (W) to an accuracy of $1 \mathrm{~g}$ and total length (TL) was measured to an accuracy of $1 \mathrm{~mm}$. Sex was determined by macroscopic examination of the gonads. Age was determined by scale reading, and validated by means of length frequency distribution (BAGENAL, 1978): the scales were removed from the left side of the fish, below the lateral line and posterior to the pectoral fins (DEVRIES and FRIE, 1996).

Diet was assessed by analysing the contents of the stomach of 275 perch and of 328 ruffe. Stomachs were extracted by dissection in the laboratory. Specimens were refrigerated in the field and then frozen at $-18^{\circ} \mathrm{C}$ about 1 hour after being removed from the nets. Owing to the long fishing time, transportation and preservation, the stomach contents probably were partially digested; thus the number of empty stomachs may have been overestimated. The stomach contents were examined under a dissecting microscope and prey items were identified to the lowest taxonomic group possible. If prey items were intact, they were counted and weighed $(0.01 \mathrm{~g})$ individually. We estimated total lengths of partially digested prey by using a computerized video image analysis system: prey-fish lengths were converted to wet weight by means of regression equations developed for Lake Piediluco; invertebrate lengths were converted to weight by means of published equations (SMOCK, 1980; LAWRENCE et al., 1987; MEYER, 1989). In the absence of available data in the literature, biomass was estimated from individuals of the same species found whole in the stomachs examined (WOLFRAM-WAIS et al., 1999): these were weighed $( \pm 0.01 \mathrm{~g})$ and their mean weight was calculated.

The diets are presented as: abundance $(\% \mathrm{~N})=$ the number of individuals of each prey category in relation to the total number of individuals; occurrence $(\% \mathrm{~S})=$ the number of stomachs containing each prey category in relation to the total number of full stomachs; weight percentage $(\% \mathrm{~W})=$ reconstructed weight of each food category in relation to the total weight of all categories found.

The index of preponderance $\left(I_{P}\right)$ of a diet component was estimated by means of the following formula (MOHAN and SANKARAN, 1988):

$$
\mathrm{I}_{\mathrm{p}}=\left(\% \mathrm{~S}_{\mathrm{i}} \% \mathrm{~W}_{\mathrm{i}}\right) / \Sigma\left(\% \mathrm{~S}_{\mathrm{i}} \% \mathrm{~W}_{\mathrm{i}}\right)
$$

where $\% \mathrm{~S}_{\mathrm{i}}$ and $\% \mathrm{~W}_{\mathrm{i}}$ are occurrence and \% weight respectively (MARSHALL and ELLIOTT, 1997). 
As an estimate of diet width we used the Levins measure of niche breadth (B) and standardized niche breadth $\left(B_{A}\right)$, which are (LEVINS, 1968):

$$
\begin{gathered}
B=1 / \Sigma p^{2}{ }_{j} \\
B_{A}=(B-1) /(n-1)
\end{gathered}
$$

respectively, where $p_{i}=$ proportion of the diet comprising prey species $j$; and $n=$ the total number of prey species. A single value is obtained, which represents the niche breadth for the species (MARSHALL and ELLIOT, 1997). The Levins measure of niche breadth (B) has a minimum of 1 when only one prey type is found in the diet and a maximum of $n$, where $n$ is the total number of prey categories, each representing an equal proportion of the diet. The Levins measure of standardized niche breadth $\left(B_{A}\right)$ ranges from 0 (diet restricted to few prey items) to 1 (generalist diet), where low values indicate food dominated by few prey items (PEDERSEN, 1999). We used Levins' indexes to calculate diet width in two ways for both species: (1) the average individual diet width and (2) the total diet width of the populations in Lake Piediluco (SVANBACK and PERSSON, 2004). The diet width of individuals was calculated from the proportion of each prey category in each individual's diet. The total diet width of the populations in Lake Piediluco was calculated from the proportion of each prey category, based on pooled data for all specimens.

The diet overlap indexes $(\alpha)$ were evaluated by using the $\% \mathrm{~W}$ of each prey category according to the following formula (SCHOENER, 1970):

$$
\alpha=1-0.5\left(\Sigma\left|p_{x i}-p_{y i}\right|\right)
$$

where $p_{x i}$ is the proportion of food item $i$ in species $x$ and $p_{y i}$ is the proportion of food item $\mathrm{i}$ in species $\mathrm{y}$. The index value varies from 0 (no diet overlap) to 1 (total diet overlap) and is used primarily when prey abundance is unknown (WALLACE, 1981). The calculation was made only on those specimens of the two species captured in the same time period; that is to say, in the years 2000-2002. The sample size considered was therefore 160 European perch and 260 ruffe.

\section{Growth}

To analyse potential changes in the growth of the perch, a growth study was carried out: the sample was made up of 1199 specimens, 291 of which were taken in the period 1998-1999, 411 in 2000-2003 and 497 in 2004-2005 in periods when the ruffe was steadily increasing in abundance (LORENZONI et al., 2005).

The absence of sexual dimorphism in the European perch is well known (THORPE, 1977; LORENZONI et al., 1993); for this reason growth analysis was carried out without taking into account the difference between sexes. Theoretical growth in length was evaluated by using Von Bertalanffy's model (1938):

$$
\mathrm{L}_{\mathrm{t}}=\mathrm{L}_{\infty}\left\{1-\exp \left[-\mathrm{k}\left(\mathrm{t}-\mathrm{t}_{0}\right)\right]\right\} \text {, }
$$

In the model, $L_{t}$ is the total length at time $t, L_{\infty}$ is the asymptotic length, $k$ is the growth rate parameter (or the rate at which $L_{\infty}$ is approached) and $t_{0}$ the age of the fish at zero length if it had always grown in a manner described by the equation. Parameter $\Phi^{\prime}$, which allows comparison of theoretical growth in length among different populations, was calculated by means of the formula (PAULY and MUNRO, 1984):

$$
\Phi^{\prime}=\log (\mathrm{k})+2 \log \left(\mathrm{L}_{\infty}\right) \text {. }
$$

These analyses were done for the three time periods (1998-99, 2000-2003 and 2004-05) separately. A comparison was made according with CHEN et al., 1992, using a F ratio: the method tests in a non linear model whether all the fitted curves describe the same population of data. 
The nutritional state of the fish captured was estimated by calculating the weight reached at the various lengths: the specimens were grouped into length-classes $(5 \mathrm{~cm}$ increments) and comparison was again made between fish caught in the periods 1998-99, 2000-2003 and 2004-05. This comparison was made by means of analysis of variance. As the weight of the European perch may be strongly influenced by the development of the gonads (LORENZONI et al., 1993), specimens caught in the pre-reproductive spring period were excluded from the analysis.

The condition of the fish captured was also estimated by using the analysis of relative weight $\left(W_{r}\right)$, on the basis of the equation (ANDERSON and NEUMANN, 1991):

$$
\mathrm{W}_{\mathrm{r}}=100\left(\mathrm{~W} / \mathrm{W}_{\mathrm{s}}\right) \text {, }
$$

where $\mathrm{W}$ is the individual weight and $\mathrm{W}_{\mathrm{s}}$ is the standard optimal weight calculated for each specimen by a regression constructed to represent the species. Constructed in this way, $\mathrm{W}_{\mathrm{r}}$ is independent of the type of growth and enables individuals and populations of different sizes to be compared. $W_{r}$ values above 100 are indicative of specimens in good condition, for which food problems should not exist. The length/weight relationship used to calculate $W_{s}$ was the following: $\log \left(W_{s}\right)=-5.386+3.23 \log (T L)(W I L L I S$ et al.,1991); this was proposed for yellow perch, a species that is morphologically and biologically indistinguishable from its Eurasian counterpart (THORPE, 1977; JENKINS and BURKHEAD, 1993). In order to limit the influence of gonadal development on weight, specimens caught in the pre-reproductive spring period were excluded from the analysis. Linear regression analysis confirmed that the index was independent from size; the relationship found between $W_{r}$ and $T L$ was: $W_{r}=95.44-0.10 T L\left(R^{2}=0.17 ; P=0.198\right) . W_{r}$ values, being independent from size, were used in subsequent comparisons.

\section{RESULTS}

\section{Composition of perch diet}

A total of 275 perch stomachs were analyzed during the investigations. The perch analyzed ranged in size from 10.5 to $36.2 \mathrm{~cm}$ in total length (TL).

The taxa found in the stomachs examined belonged to 5 different animal classes (Table I). The category "other" included seeds and vegetable remains, which could not be determined more accurately; their presence in the stomachs of the European perch is only occasional (MANN, 1978). Insects, in particular Chironominae larvae and pupae, clearly constitute the largest component of the European perch's diet, in terms of both frequency $(\% \mathrm{~N}=38.49$ and 15.17$)$ and biomass quantity $(\% \mathrm{~N}=17.67$ and 26.61$)$. The most frequently found category of crustaceans was that of gammarids $(\% \mathrm{~S}=29.11)$, which also constituted the largest category in terms of weight $(\% \mathrm{~W}=14.15)$; in numerical terms, however, gammarids $(\% \mathrm{~N}=15.53)$ were fewer than cladocerans $(\% \mathrm{~N}=15.57)$. The diet of the European perch also includes small fish of diverse species (rudd, ruffe and roach). Generally, the fish content of the stomachs examined was scant and infrequent, though important in terms of weight. Anellids and molluscs (gastropods and bivalves) complete the picture of the diet of the European perch in Lake Piediluco.

Dipterans were an important component of the European perch's diet at all ages, though in older specimens piscivory was increasingly observed (Figure 2). Benthic crustaceans, even though found in fish of all ages, tend to be consumed more by the central age-classes, while they are less important in the 1+ and 5+ age-groups. Zooplankton is also present in the stomachs of fish of all age-groups, but is more abundant in the diet of the 1+ age-group. The categories "other insects" and "other" are not important components of the European perch's diet. 


\section{Table I}

List of taxa found in the stomachs of perch and ruffe: the diets are expressed as relative abundance $(\% \mathrm{~N})$, relative occurrence $(\% \mathrm{~S})$, relative weight $(\% \mathrm{~W})$ and index of preponderance $\left(I_{p}\right)$.

Tableau I

Liste des taxa observés dans les estomacs de la perche et de la grémille: les régimes alimentaires sont exprimés en abondance $(\% \mathrm{~N})$, occurrence $(\% \mathrm{~S})$, pourcentage de poids $(\% \mathrm{~W})$ et indice de prépondérance $\left(I_{p}\right)$.

\begin{tabular}{|c|c|c|c|c|c|c|c|c|}
\hline & \multicolumn{4}{|c|}{ Perch } & \multicolumn{4}{|c|}{ Ruffe } \\
\hline & $\% \mathrm{~N}$ & $\% \mathrm{~S}$ & $\% \mathrm{~W}$ & $I_{P}$ & $\% \mathrm{~N}$ & $\% \mathrm{~S}$ & $\% \mathrm{~W}$ & $I_{P}$ \\
\hline \multicolumn{9}{|l|}{ Anellida } \\
\hline Hirudinea & 0.202 & 6.573 & 1.009 & 0.00181 & 0.069 & 0.730 & 0.497 & 0.00007 \\
\hline \multicolumn{9}{|l|}{ Mollusca } \\
\hline Gasteropoda & 0.020 & 1.878 & 0.017 & 0.00001 & - & - & - & - \\
\hline Bivalvia & 0.167 & 7.981 & 0.029 & 0.00006 & - & - & - & - \\
\hline \multicolumn{9}{|l|}{ Crustacea } \\
\hline Cladocera & 15.567 & 7.981 & 0.014 & 0.00003 & - & - & - & - \\
\hline Copepoda & 9.772 & 3.756 & 0.028 & 0.00003 & - & - & - & - \\
\hline Gammaridae & 15.526 & 29.108 & 14.154 & 0.11218 & 7.418 & 24.818 & 7.663 & 0.03641 \\
\hline Asellidae & 0.536 & 11.737 & 0.231 & 0.00074 & 1.168 & 7.664 & 0.482 & 0.00071 \\
\hline Conchostraca & 0.030 & 2.817 & 0.003 & 0.00000 & 4.842 & 9.489 & 0.500 & 0.00091 \\
\hline \multicolumn{9}{|l|}{ Insecta } \\
\hline \multicolumn{9}{|l|}{ Diptera Chironominae } \\
\hline \multicolumn{9}{|c|}{ Diptera Chironominae } \\
\hline pupae & 15.167 & 71.362 & 26.608 & 0.51701 & 10.749 & 34.672 & 25.544 & 0.16954 \\
\hline Diptera Tanypodinae & 4.236 & 4.225 & 1.087 & 0.00125 & 3.177 & 5.109 & 0.984 & 0.00096 \\
\hline Diptera Simuliidae & 0.010 & 0.939 & 0.069 & 0.00002 & - & - & - & - \\
\hline Ephemeroptera & 0.010 & 0.939 & 0.006 & 0.00000 & 0.189 & 2.920 & 0.059 & 0.00003 \\
\hline Eteroptera & 0.025 & 1.878 & 0.024 & 0.00001 & - & - & - & - \\
\hline Megaloptera Sialidae & 0.127 & 2.817 & 0.277 & 0.00021 & 7.727 & 33.942 & 20.642 & 0.13412 \\
\hline Odonata & 0.005 & 0.469 & 0.017 & 0.00000 & - & - & - & - \\
\hline Trichoptera & 0.015 & 1.408 & 0.104 & 0.00004 & 0.069 & 1.095 & 0.568 & 0.00012 \\
\hline Insecta non det. & & & & & 0.137 & 2.920 & 0.115 & 0.00006 \\
\hline \multicolumn{9}{|l|}{ Pisces } \\
\hline \multicolumn{9}{|l|}{ Gymnocephalus } \\
\hline Rutilus rutilus & 0.005 & $\begin{array}{l}1.400 \\
0.469\end{array}$ & $\begin{array}{l}10.390 \\
3.466\end{array}$ & 0.00044 & - & - & - & - \\
\hline Perca fluviatilis & 0.005 & 0.469 & 3.466 & 0.00044 & - & - & - & - \\
\hline $\begin{array}{l}\text { Scardinius } \\
\text { erythrophthalmus }\end{array}$ & 0.005 & 0.469 & 3.466 & 0.00044 & - & - & - & - \\
\hline \multicolumn{9}{|c|}{ Pisces non determinata } \\
\hline & 0.025 & 2.347 & 17.330 & 0.01107 & - & - & - & - \\
\hline Others & 0.035 & 0.939 & 0.030 & 0.00001 & - & - & - & - \\
\hline Non determinata & 0.005 & 0.469 & 0.497 & 0.00006 & - & - & - & - \\
\hline
\end{tabular}




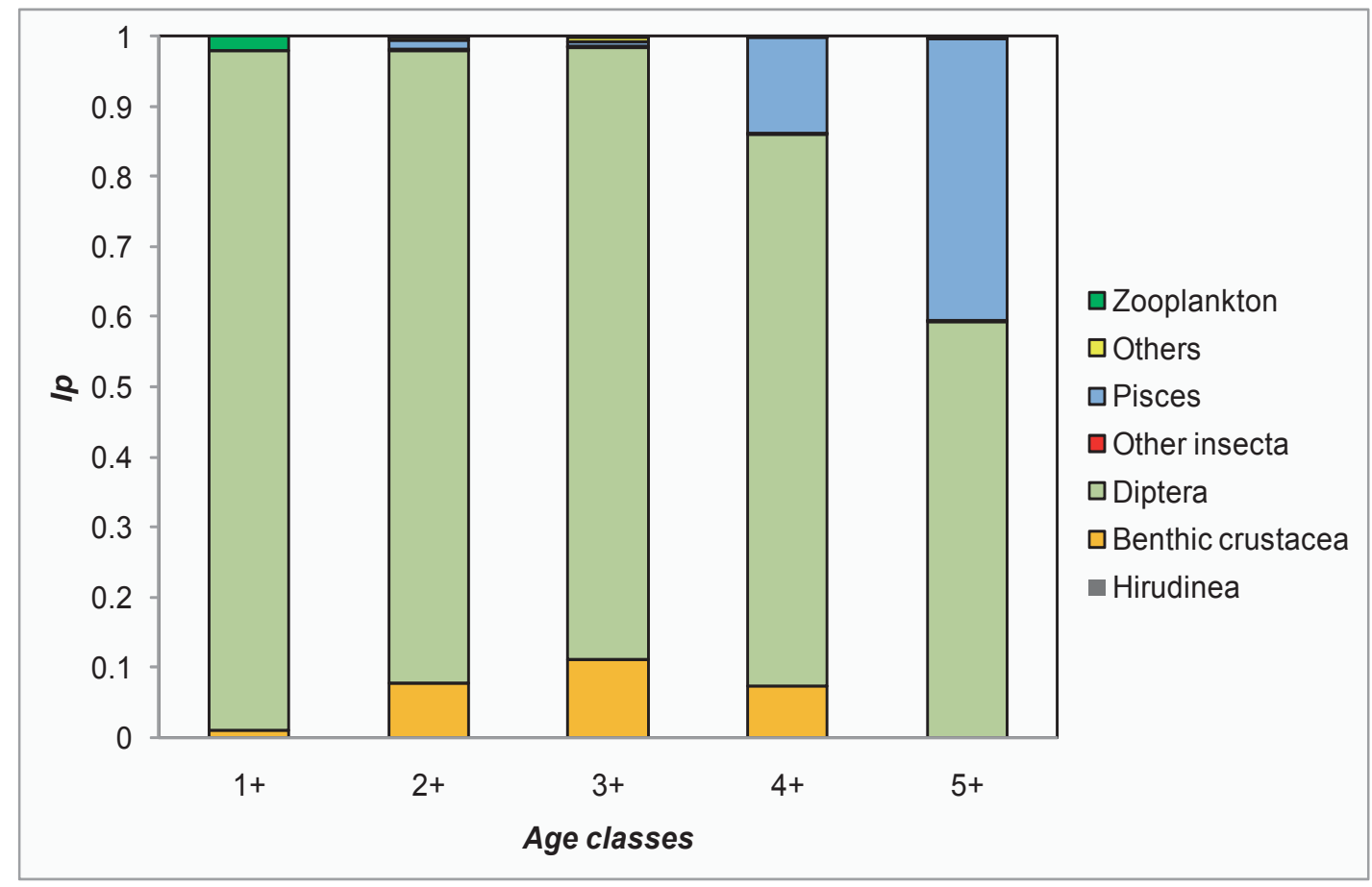

Figure 2

Index of preponderance $\left(I_{P}\right)$ in the European perch stomach samples broken down by age-class.

Figure 2

Indice de prépondérance $\left(I_{p}\right)$ dans l'échantillon de la perche commune, discriminé par classe d'âge.

Table II

Levins' indexes ( $B$ and $B_{A}$ ) of perch and ruffe: descriptive statistics of individual values and total diet width based on pooled data for all specimens.

Tableau II

Indices de Levins (B et $\mathrm{B}_{\mathrm{A}}$ ) de la perche et de la grémille: statistiques descriptives des valeurs individuelles et amplitude totale du régime alimentaire à partir de données groupées pour tous les spécimens.

Pooled Levins'

indexes

\begin{tabular}{lcccccccc}
\hline & & $\mathrm{N}$ & Average & Median & Min. & Max. & Std Dev & \\
\hline \multirow{2}{*}{ perch } & $\mathrm{B}$ & 213 & 1.452 & 1.281 & 1.000 & 3.789 & 0.540 & 4.332 \\
\cline { 2 - 9 } & $\mathrm{B}_{\mathrm{A}}$ & 213 & 0.277 & 0.150 & 0.000 & 1.000 & 0.301 & 0.145 \\
\hline \multirow{2}{*}{ ruffe } & $\mathrm{B}$ & 273 & 1.495 & 1.290 & 1.000 & 3.806 & 0.565 & 2.262 \\
\cline { 2 - 8 } & $\mathrm{B}_{\mathrm{A}}$ & 273 & 0.317 & 0.216 & 0.000 & 1.000 & 0.334 & 0.126 \\
\hline
\end{tabular}


The Levins index $(B)$, calculated for the entire sample is 4.332 , while Levins' standardized index $\left(B_{A}\right)$ is 0.145 . The average individual values of $B$ and $B_{A}( \pm 1 S D)$ are $1.452( \pm 0.540)$ and $0.277( \pm 0.301)$, respectively (Table II).

\section{Composition of ruffe diet}

A total of 328 ruffe stomachs were analyzed during the investigations. The specimens analyzed ranged from 6.1 to $21.0 \mathrm{~cm}$ in total length (TL). The most important food categories found in the stomachs of ruffe were those of Chironominae larvae $(\% \mathrm{~N}=64.46 ; \% \mathrm{~W}=42.94 ; \% \mathrm{~S}=79.93)$ and pupae $(\% \mathrm{~N}=10.75 ; \% \mathrm{~W}=25.54 .94 ; \% \mathrm{~S}=34.67)$. In addition, there were Sialidae $(\% \mathrm{~N}=7.73 ; \% \mathrm{~W}=20.64 ; \% \mathrm{~S}=33.94)$ and Gammaridae $(\% \mathrm{~N}=7.42 ; \% \mathrm{~W}=7.66 ; \% \mathrm{~S}=24.82)$ which reach the highest levels of abundance (Table I).

The data showed that the most abundant $(\% \mathrm{~N})$ and most frequent $(\% \mathrm{~S})$ food source at all ages was dipterans (Figure 3). Benthic crustaceans and "other insects" were abundant, the former being mostly consumed in the first years of life. It is evident from the graph that there was an opposing trend between "other insects" and Diptera; with age, the consumption of "other insects" declined, and predation on dipterans increased. In the 2+ and 3+ age-groups, Hirudinea were also occasionally found, while they were completely absent in the 1+ and 4+ classes.

Levins' index, calculated for the entire sample was 2.262, while Levins' standardized index was 0.126 . The average individual values of $B$ and $B_{A}( \pm 1 S D)$ were $1.495( \pm 0.565)$ and $0.317( \pm 0.334)$, respectively (Table II).

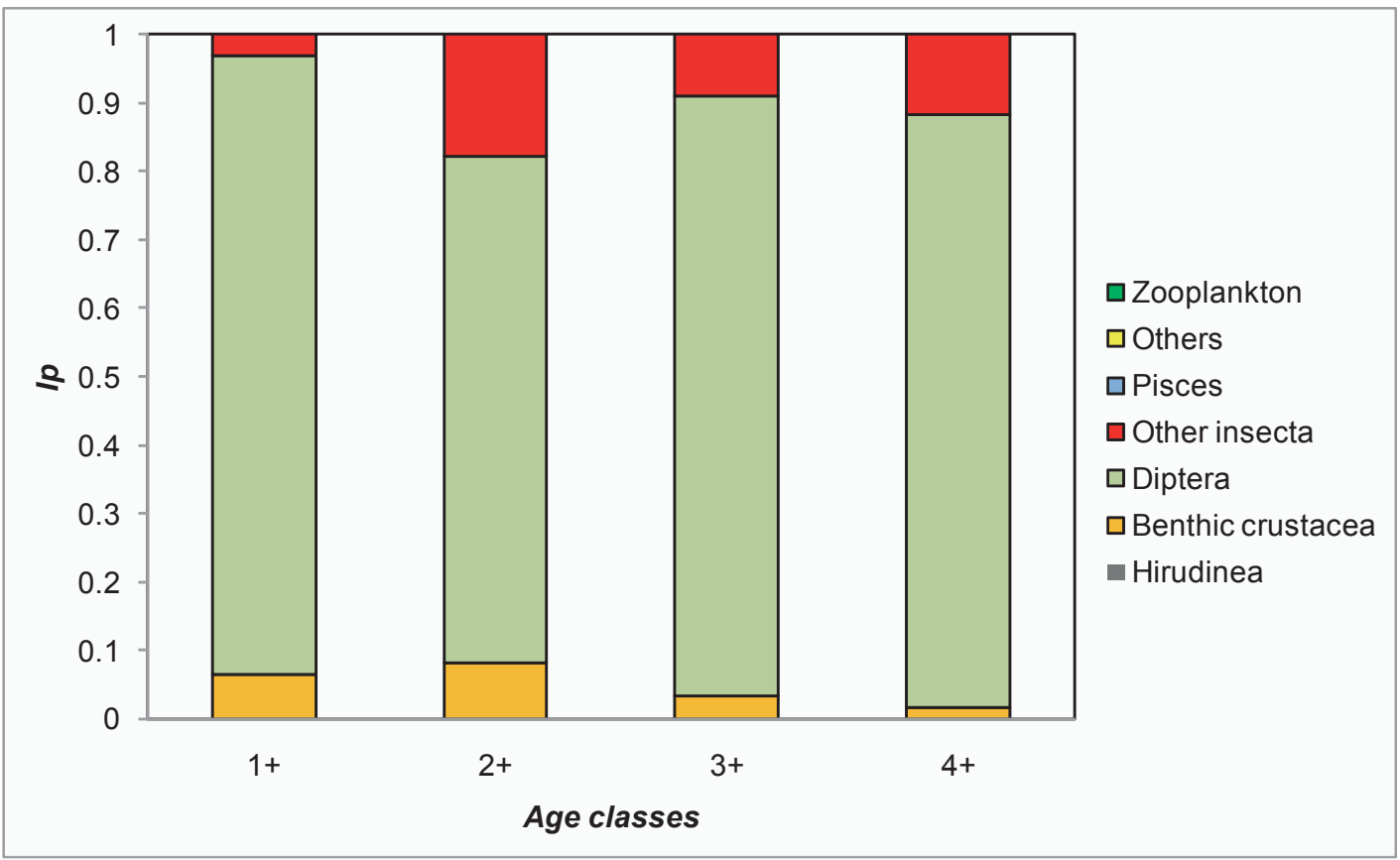

\section{Figure 3}

Index of preponderance $\left(I_{p}\right)$ in the ruffe stomach samples broken down by ageclass.

\section{Figure 3}

Indice de prépondérance $\left(I_{p}\right)$ dans l'échantillon de la grémille, discriminé par classe d'âge. 


\section{Diet overlap}

In terms of biomass, the greatest overlap between the diets of the two species was seen in the $1+$ age-classes $(\alpha=0.853)$, while the smallest overlap was recorded between perch aged $5+(\alpha=0.394)$ and ruffe aged $2+$ (Figure 4$)$; if the sample is not broken down into age-classes, the value of diet overlap is 0.659 . If the sample of perch broken down into age-classes is compared with the whole sample of ruffe, the least diet overlap is seen in the $1+$ age-class of the perch $(\alpha=0.720)$ : in general, values indicate a high degree of diet overlap in the younger age-classes $(1+, 2+$ and $3+)$ and a trend towards greater diversification as the age of the perch increases.

\section{Growth of perch}

Growth analysis of the European perch was conducted on a sample of 1199 fish, the total length of which ranged from 6.00 to $36.20 \mathrm{~cm}$ (Table III). The theoretical growth in length for the whole period is described by the equation TL=42.07(1-exp $\left.{ }^{-0.171(t+0.756)}\right)$ $\left(R^{2}=98.99 \%\right)$; the value of $\Phi^{\prime}$ is 2.48 . Comparison with the results of previous research (Table IV) show that the maximum size $\left(L_{\infty}\right)$ and the values of the parameter $\Phi$ ' have increased (PAULY and MUNRO, 1984). Nevertheless, closer analysis of the data reveals that the growth of the European perch has steadily worsened in recent years, as shown by the reduction in the value of $\Phi^{\prime}$. Indeed, the theoretical growth in length during the 199899 period was described by the equation $T L=50.27\left(1-\exp ^{-0.128}(t+0.870)\right)\left(R^{2}=89.58 \%\right)$ and the value of $\Phi^{\prime}$ 'was 2.51 ; for the $2000-03$ period, the equation was $T L=43.01$ (1-exp ${ }^{-0.171}$ $\left.{ }^{(t+0.738)}\right)\left(R^{2}=90.69 \%\right)$, with $\Phi^{\prime}$ equal to 2.50 ; for the 2004-05 period, the equation was $T L=$ $43.08\left(1-\exp ^{-0.158(t+0.895)}\right)\left(R^{2}=94.25 \%\right)$, with $\Phi^{\prime}$ equal to 2.49 (Figure 5). There were highly significant differences $(P<0.01)$ between the three curves at the statistical test $(F=37.22)$.

\section{INDEX OFDIET OVERLAP $(\alpha)$}

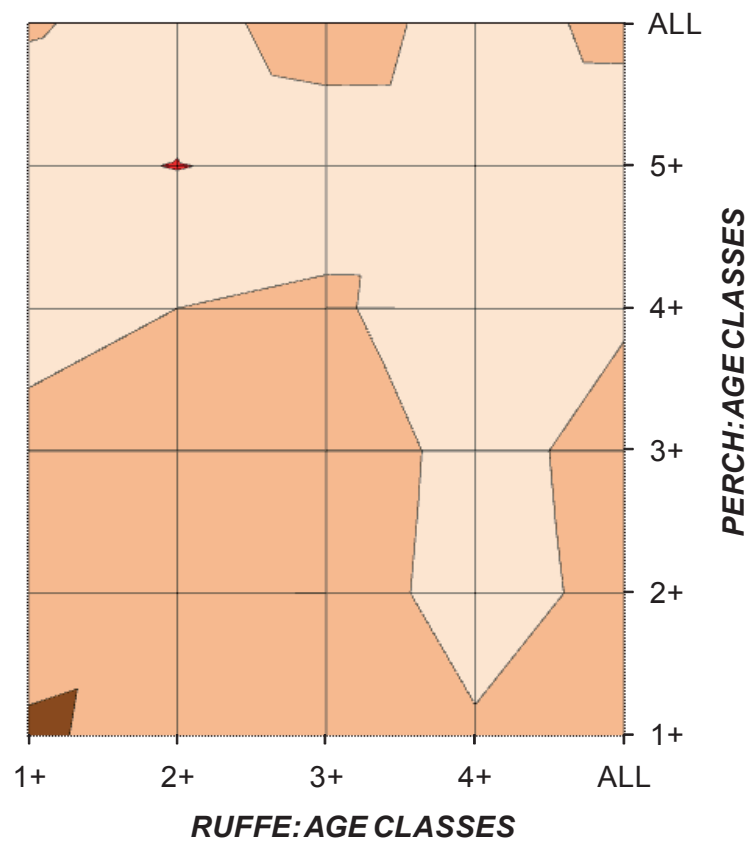

$\square 0.800-1.000$

$\square 0.600-0.800$

$\square 0.400-0.600$

$\square 0.200-0.400$

$\square 0.000-0.200$

\section{Figure 4}

Interspecific diet overlap (Schoener's index $\alpha$ ) between the different age classes of ruffe and perch in Lake Piediluco.

\section{Figure 4}

Chevauchement alimentaire interspécifique (indice de Schoener $\alpha$ ) entre la grémille et la perche dans les lac de Piediluco. 


\section{Table III}

Descriptive statistics of the sample used for the growth analysis of the European perch.

Tableau III

Statistique descriptive de l'échantillon utilisé pour l'analyse de la croissance de la perche commune.

\begin{tabular}{lcccccc}
\hline & $\mathrm{N}$ & Average & Median & Min. & Max. & Dev.Std. \\
\hline LT (cm) & 1199 & 18.40 & 18.00 & 6.00 & 36.20 & 4.61 \\
Weight (g) & 1199 & 102.58 & 78.00 & 1.50 & 904.00 & 87.43 \\
Age (yr) & 1199 & 2.67 & 2.42 & 0.10 & 8.00 & 1.15 \\
\hline
\end{tabular}

\section{Table IV}

European perch: parameters of Von Bertalanffy's equation calculated at different times.

Tableau IV

Perche commune: paramètres de l'équation de Von Bertalanffy calculés à différentes périodes.

\begin{tabular}{lcccc}
\hline \multicolumn{1}{c}{ Research } & Year & $\mathrm{L}_{\infty}(\mathrm{cm})$ & $\mathrm{k}\left(\mathrm{y}^{-1}\right)$ & $\Phi^{\prime}$ \\
\hline Giovinazzo, 1988 & 1980 & 18.76 & 0.408 & 2.16 \\
Enel, 1989 & 1988 & 27.73 & 0.212 & 2.21 \\
Present study & $1998-2005$ & 42.07 & 0.171 & 2.48 \\
Present study & $1998-1999$ & 50.27 & 0.127 & 2.51 \\
Present study & $2000-2003$ & 43.01 & 0.172 & 2.50 \\
Present study & $2004-2005$ & 43.08 & 0.158 & 2.47 \\
\hline
\end{tabular}

In the most recent years, the weight reached by the various length-classes of the European perch has also declined progressively (Figure 6). Indeed, the mean weight of perch in Lake Piediluco in the period 1998-99 was greater than in the period 2000-03, which was, in turn, greater than in 2004-05. The only exceptions to this pattern were seen in the $7.5 \mathrm{~cm}$ length-class (2000-03>1998-99) and in the $32.5 \mathrm{~cm}$ length-class (2000-03>2004-05>1998-99). The differences between the observation periods proved to be significant (ANOVA) with regard to the $7.5 \mathrm{~cm}(\mathrm{~F}=11.82 ; \mathrm{P}=0.000), 12.5 \mathrm{~cm}(\mathrm{~F}=3.06$; $P=0.049)$ and $17.5 \mathrm{~cm}$ length-classes $(F=24.10 ; P=0.000)$, but not with regard to larger specimens (22.5 cm: $F=0.20 ; P=0.816),(27.5 \mathrm{~cm}$ : $F=0.04 ; P=0.861),(32.5 \mathrm{~cm}: F=0.25$; $\mathrm{P}=0.786)$.

The relative weight calculated for the entire perch sample was rather variable from one year to another, showing highly significant differences (ANOVA: $F=18.06 ; P=0.000$ ) in the average values. However, a significant trend toward a decrease in relative weight over time can be seen for the overall sample (Figure 7). 


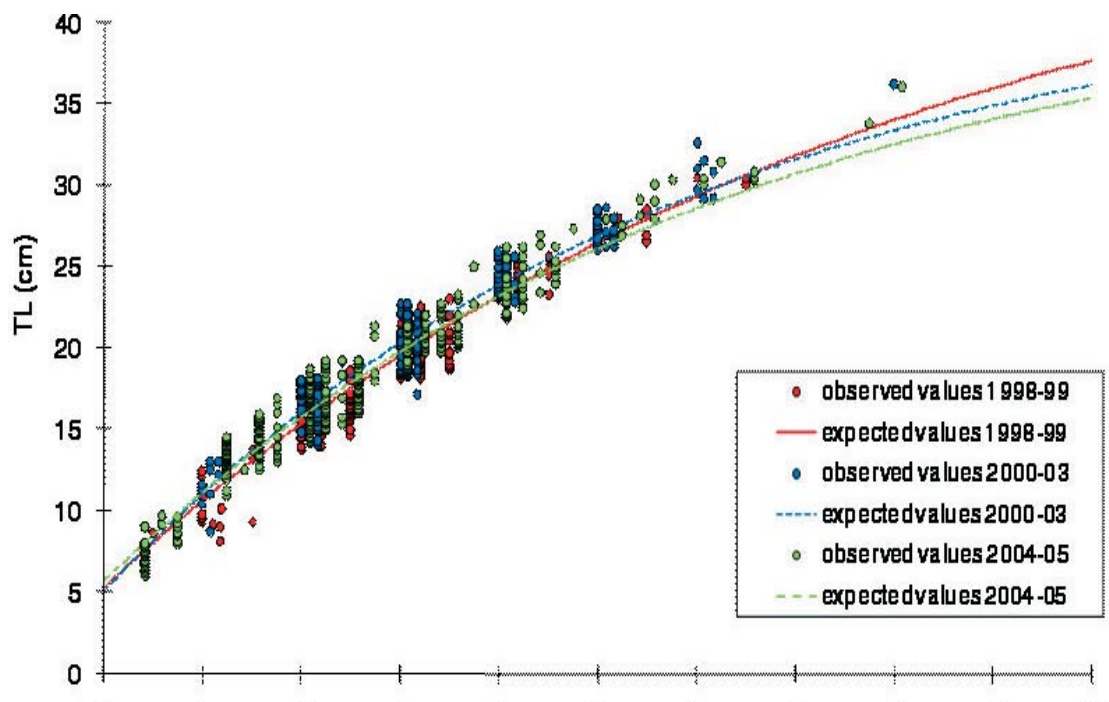

Figure 5

Theoretical growth in length of the European perch in different periods (199899; 2000-03; 2004-05): the lines show the values obtained by applying the Von Bertalanffy model to the data recorded (shown by individual points).

Figure 5

Croissance en longueur théorique de la perche commune à différentes périodes (1988-99; 2000-03; 2004-05): les lignes constituent les valeurs obtenues en appliquant le modèle de Von Bertalanffy aux données relevées, représentées par les points.

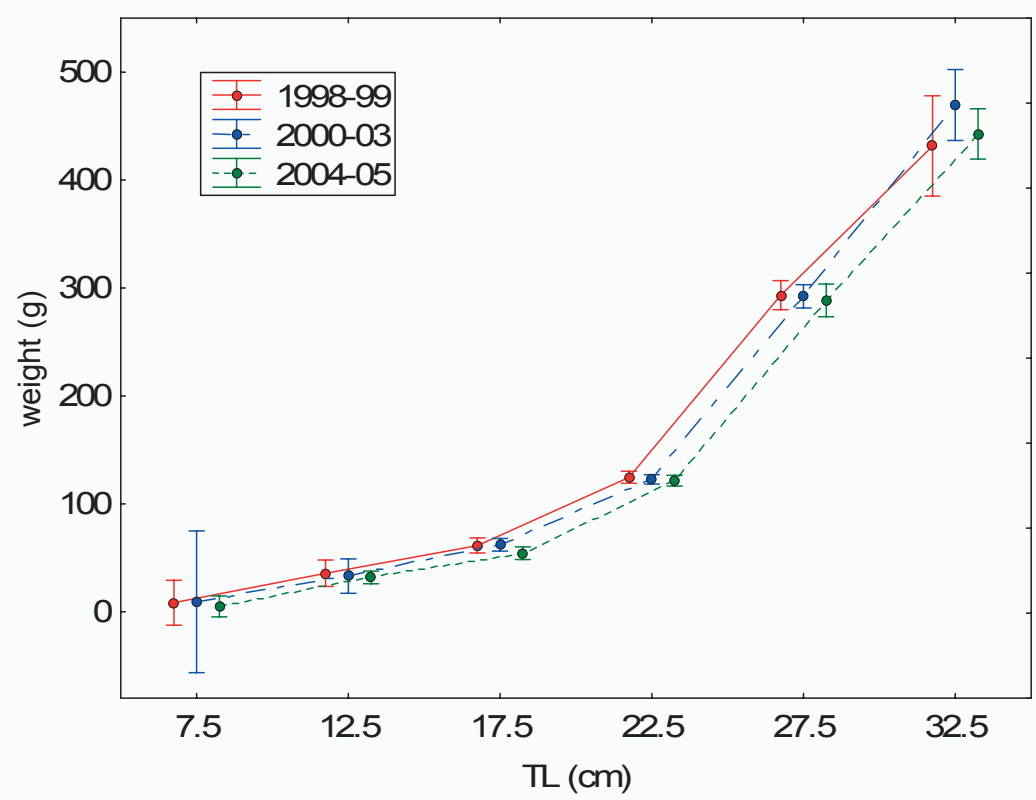

Figure 6

Weight in different size classes $(5 \mathrm{~cm}$ intervals) of the European perch: mean values in different periods (1998-99; 2000-03; 2004-05) with 95\% confidence limits.

Figure 6

Poids en fonction de l'âge de la perche commune: valeurs moyennes à des périodes différentes (1998-99; 2000-03; 2004-05) avec des limites de confiance de 95\%. 


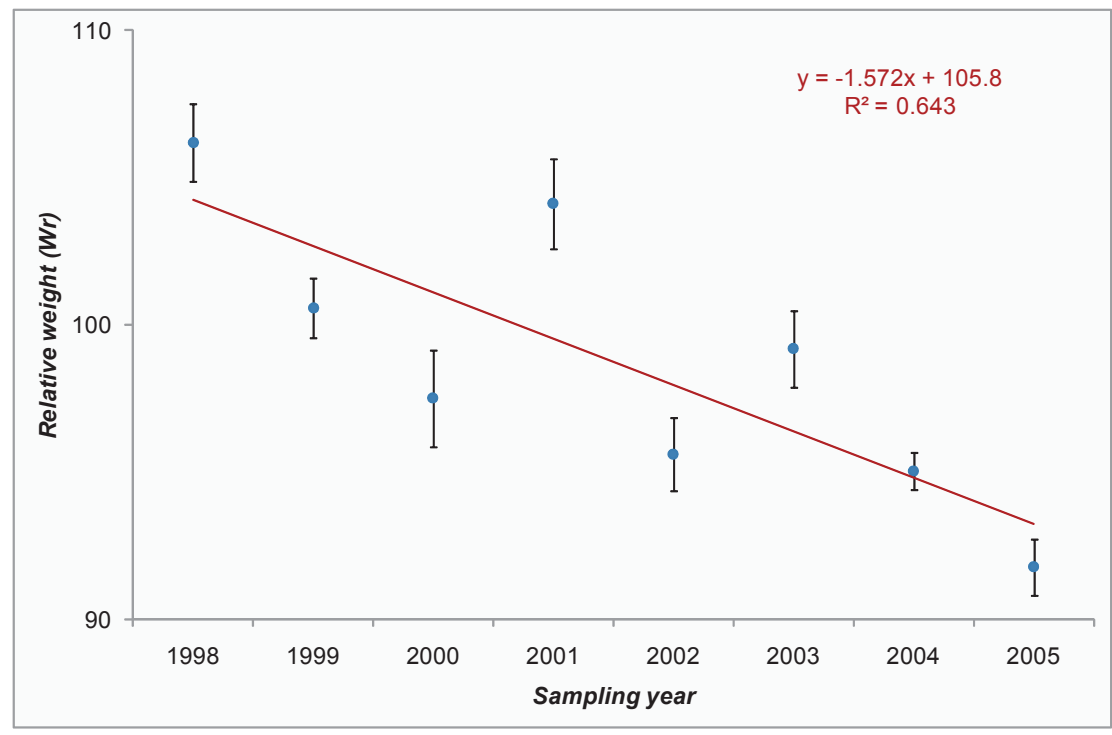

Figure 7

Temporal trend in the relative weight $\left(\mathrm{W}_{\mathrm{r}}\right)$ of the European perch: mean values for the whole sample in different sampling years, with $95 \%$ confidence limits. Red line represents linear regression of equation $W_{r}=105.8-1.57 y r\left(R^{2}=64.30 \%\right)$.

\section{Figure 7}

Évolution temporelle du poids relatif $\left(\mathrm{W}_{\mathrm{r}}\right)$ de la perche commune: valeurs moyennes de tout l'échantillon lors de différentes années d'échantillonnage. avec limites de confiance de $95 \%$. La ligne rouge représente la régression linéaire de l'équation $\mathrm{W}_{\mathrm{r}}=105.8-1.57 \mathrm{yr}\left(\mathrm{R}^{2}=64.30 \%\right)$.

\section{DISCUSSION}

Eutrophication of lakes induces changes in abiotic and biotic environmental factors, which are reflected in the structure of the fish assemblage (OLIN et al., 2002). In temperate lakes in Europe, the characteristic shift along a productivity gradient is from the dominance of salmonids in oligotrophic lakes to the dominance of cyprinids in highly productive lakes. European perch attain their highest population biomass under mesotrophic conditions (BERGMAN and GREENBERG, 1994). One of the most important factors in the decrease in perch and increase cyprinids biomasses is diminishing light intensity under eutrophic conditions. The perch is a visually oriented predator and its foraging efficiency is severely reduced in turbid water (SCHLEUTER and ECKMANN, 2006 and 2007). European perch stocks in Lake Piediluco have dwindled as the water has become increasingly eutrophic, a process which began before the introduction of the ruffe (LORENZONI et al., 2005).

Food availability and population density affect the growth rate of perch (SHAFY and MAITLAND, 1971; PAUKERT and WILLIS, 2001): low perch density and abundant invertebrate food organisms are probably the most important determinants of this change in growth (HOUTHUIJZEN et al., 1993; DÖRNER et al., 2003). It is well known that this species displays mechanisms of density-dependent growth compensation, whereby the maximum possible size increases (CRAIG and KIPLING, 1983; HOLMGREN and APPELBERG, 2001). SCHAEFFER et al. (2000) suggested that eutrophic conditions in Saginaw Bay, Lake Huron, led to increased chironomid production and improved feeding conditions for perch; moreover, an increase in zoobenthic abundance and diversity has been seen to determine the best growth rates in the yellow perch (TYSON and KNIGHT, 
2001). In the altered ecological conditions of Lake Piediluco, benthic invertebrate fauna has become more productive, with a dominance of species, such as chironomids, that can tolerate low oxygen conditions. In 1980 the average density of crustaceans and dipteran larvae was 91 and 79 ind $\mathrm{m}^{-2}$ respectively; these values increased to 269 and 299 ind $\mathrm{m}^{-2}$ in the years 2000-2002. This increase in the density of benthic organisms, however, might also be a consequence of the reduced pressure of predation by a declining perch stock and of the limited ability of this species to forage at increasing turbidity. The perch's improved growth in Lake Piediluco, in comparison with the years in which the lake was mesotrophic, is also due to the fact that the diet of this species is currently broader and includes more fish than formerly (GIOVINAZZO, 1988). Indeed, an increase in fish-eating is strongly correlated with an improvement in growth (THORPE, 1977; BEECK et al., 2002; HOLMGREN, 2003).

It is in this environmental context that the most recent interaction between the European perch and the ruffe can be viewed. The increased abundance of the ruffe, which displays a potential for considerable further expansion, is likely to engender new problems for future perch stocks in Lake Piediluco. Most studies agree that juvenile perch and ruffe are potential competitors for benthic macro-invertebrates (BERGMAN and GREENBERG 1994; DIETERICH et al., 2004; FULLERTON et al., 1998). The ruffe is a mechano-sensory oriented predator which has a well-developed lateral line organ and a light-sensitive eye; consequently, it can forage more efficiently than perch in eutrophic turbid waters (SCHLEUTER and ECKMANN, 2006 and 2007).

Perch and ruffe exhibit contrasting feeding strategies (SCHLEUTER and ECKMANN, 2007). The ruffe is a specialised benthos consumer, while perch feed on a broader range of prey. In general, the ruffe changes its diet little after switching to feeding primarily on macrobenthos early in life (OGLE, 1998): after a very short plankton-feeding stage in the larval phase, it switches to zoobenthos, with chironomids being its preferred prey throughout its life (REZSU and SPECZIAR, 2006; SCHLEUTER and ECKMANN, 2007). In Lake Piediluco its feeding preference changed slightly with age, especially from a quantitative point of view. Chironomids are the preferred food at all ages, while in the oldest fish the consumption of crustaceans is gradually substituted by that of greater amounts of Sialis, a megalopteran that ruffe apparently select (BERGMAN and GREENBERG, 1994).

The differences between the two species emerge most clearly when their diets are analysed in relation to the ages of the specimens. The values of the Levins indexes show that the total niche width of the perch is almost double $(B=4.332)$ that of the ruffe $(B=2.262)$. Even the values of Levins' standardized index reached by the European perch $\left(B_{A}=0.145\right)$ are higher than those of the ruffe $\left(B_{A}=0.126\right)$. The differences between the two species are less pronounced in this case, indicating that the wider niche width of the perch is largely due to a more composite and varied food choice. Differences between the Levins' indexes calculated for the entire population $\left(B=4.332 ; B_{A}=0.145\right)$, as opposed to average values $( \pm 1 S D)$ calculated on single individuals $\left(B=1.452 \pm 0.540 ; B_{A}=0.277 \pm 0.301\right)$, confirm that important changes in the perch's diet take place during ontogenesis. Ontogenetic diet shifts and individual feeding specialisation are both characteristic of the perch, which is a food generalist (REZSU and SPECZIAR, 2006; SCHLEUTER and ECKMANN, 2007). Like many animal populations, perch seem to have generalized diets; however, each individual may have a more restricted diet. Indeed, within-population niche differentiation can occur in a number of ways, one of which is ontogenetic shift (SVANBACK and PERSSON, 2004). During development, the perch's diet undergoes changes. The diet of older perch includes rudd, ruffe and roach); one case of cannibalism, which is found rather frequently in this species (HORPPILA et al., 2000; BARAS et al., 2003), was also observed by us. These changes show some differences in comparison with the past, in that diet differences among age-groups now seem to be more pronounced. Previous research did not find these quantitative changes in feeding behaviour, which in Lake Piediluco remained essentially benthivore in all age-classes above 1+ (GIOVINAZZO, 1988). 
Diet overlap between perch and ruffe in Lake Piediluco is high, $\alpha$ being equal to 0.659 for the total sample of these two species. In the samples broken down into ageclasses the maximum $\alpha$ value was 0.853 (between perch $1+$ and ruffe $1+$ ). This confirms concerns about the existence of a negative interaction between the two species. MACEINA and MURPHY (1988) considered an index of 0.80 to indicate a high degree of similarity in diet, and PEDERSEN (1999) has interpreted values above 0.74 as indicative of high overlapping. Values above 0.60 must be considered biologically significant and indicative of inter-species competition if resources are limited (ZARET and RAND, 1971; LORENZONI et al., 2002; HORSTKOTTE and STRECKER, 2005). SCHLEUTER and ECKMANN (2007) consider a value of $\alpha>0.5$ to indicate high diet overlap between the European perch and the ruffe in Lake Constance. When analysed according to age-classes, diet overlap between the European perch and the ruffe in Lake Piediluco is seen to be highest in the $1+(\alpha=0.720), 2+(\alpha=0.664)$ and $3+$ classes $(\alpha=0.677)$, while the overlap decreases with age as a result of the feeding preferences that take place in the European perch during ontogenesis. REZSU and SPECZIAR (2006) found that the diets of the European perch and the ruffe in Lake Balaton display a very weak overlap between the 31-120 mm (Standard Length) ruffe and the 21-40 $\mathrm{mm}$ perch.

Diet overlap may be overestimated by the low resolution of the analysis: further investigations are needed to examine whether or not ruffe and perch consume different chironomid groups. In any case, studies conducted on the benthos in Lake Piediluco have documented a high degree of homogeneity; the Chironominae sub-family is made up almost entirely of the species Chironomus plumosus, while the only representative of the Tanipodinae sub-family is the genus Procladius (GORETTI et al., 2004).

Competition among sympatric species that use the same food resources is not inevitable, but it can be relieved by division of diverse resources (HODGSON et al., 1997). Competition between two species could be alleviated by a different spatial or temporal use of resources (ARMSTRONG et al., 1998). In particular, significant differences in the choice of habitat seem to be effective in ensuring co-existence among species using the same food source (WERNER et al., 1981; SCOTT and ANGERMEIER, 1998; FULLERTON and LAMBERTI, 2006). BERGMAN (1988) demonstrated habitat partitioning between the two species in Swedish lakes, with perch living in the lighter, shallower zones, and ruffe being more abundant in deeper regions with lower light intensity. The interaction between the ruffe and the European perch does not, however, seem to fall into this category, as the two species currently colonize the entire lake (LORENZONI et al., 2005). Recent studies have demonstrated that resource partitioning between perch and ruffe may also include differences in their substrate preferences and diel activity (FULLERTON and LAMBERTI, 2006; REZSU and SPECZIAR, 2006; SCHLEUTER and ECKMANN, 2007). Significant diet overlap may not be followed by true competition even if the resources available are very abundant. To assess diet overlap between ruffe and yellow perch, FULLERTON et al. (1998) carried out laboratory experiments in which they studied the preferences of the species for benthic invertebrates: perch were not negatively affected by the presence of ruffe as long as the food supply was abundant; when it was scarce, however, consumption by perch decreased dramatically, particularly under inter-specific competition. The high degree of diet overlap may, however, evolve over time, and diminish as a result of a niche divergence induced by very intense inter-specific competition (SCHLEUTER and ECKMANN, 2007). Indeed, competition has not been documented in lakes where the two species co-evolved, while the presence of the ruffe seems particularly to penalise the perch in recently invaded lakes (FULLERTON and LAMBERTI, 2006).

Nevertheless, our research seems to indicate that the presence of the ruffe in Lake Piediluco may well be impacting negatively on the perch, especially if ruffe stocks continue to grow at their present rate. In Lake Piediluco the hypothesis of a negative interaction between the two species, and of its rapid evolution, is confirmed by the general state of the European perch's growth and by the analysis of its trend over time. 
A trend towards improved growth among European perch was initially seen as the status of the lake changed from mesotrophic to eutrophic, in the years before the arrival of the ruffe. In the most recent years, however, this trend seems to have been reversed. In Lake Constance, too, the increase in ruffe abundance coincided with a decrease in the growth rate of perch. However, this decline in the growth of perch seems mainly to be a result of the oligotrophication of the lake (SCHLEUTER and ECKMANN, 2007). In pond enclosures (BERGMANN and GREENBERG, 1994) and aquaria (FULLERTON et al., 2000), the growth of perch has been seen to decline as the density of ruffe increases, suggesting that competition for food is possible (FULLERTON and LAMBERTI, 2006). Although it cannot be demonstrated that the presence of the ruffe has had a direct influence on the growth of the European perch in Lake Pediluco, all of the analyses carried out have shown that perch growth has worsened as ruffe stocks have increased. Indeed, the trend in theoretical growth in length calculated for different years since the first appearance of the ruffe displays shows a progressive worsening in $\Phi^{\prime}$ values over time. Moreover, the mean weight reached by the various length-classes of the European perch has also steadily diminished in recent years. This trend is also confirmed by the data on relative weight: values of $W_{r}$ above 100 are an index of fish in good health, for which there should be no food problem. In addition, over time, the average weight at length is particularly penalized in the youngest age groups; that is to say, precisely in those in which the diet overlap with the ruffe is greatest.

\section{CONCLUSION}

The results of our research show that the problems of the European perch in Lake Piediluco are varied and complex. Problems related to the introduction of some exotic fish species constitute a further negative element that can be added to changes in the trophic state and the general environmental worsening that has been in progress in recent years. One of the most important factors in the decrease in perch and increase in roach, northern Italian roach and ruffe biomasses is diminishing light intensity under eutrophic conditions. Indeed, perch need light in order to locate their prey, whereas under eutrophic, low-light conditions, the competitive superiority of cyprinids and ruffe over perch in foraging for zooplankton and zoobenthos is enhanced. In addition to the European perch, the pike, which is the only other fish-eating predator in the lake, has also declined in numbers; this has constituted a further advantage for the pabulum species.

In this context, the introduction of the ruffe and its rapid numerical increase is an added reason for worry. Diet overlap between the ruffe and the European perch is high and confirms concerns over the interaction between the two species. This interaction seems to be in rapid progression, and its negative impact on the European perch mostly concerns the younger age-groups, which are clearly benthivorous. The presence of the newly introduced roach can represent an ulterior threat for the perch: in other European lakes (PERSSON and GREENBERG, 1990) very intense food competition for zooplankton exists between young roach and European perch (BERGMAN, 1990).

Given the current environmental conditions of Lake Piediluco, it is clear that the quality of its waters can only be restored by intercepting inflowing nutrient loads. Nevertheless, in the meantime, intervention on the structure of the fish community should immediately be undertaken. Bio-manipulation through a stocking programme of piscivorous fish (such as pike, eel and large perch) could contribute to changing the food-web structure by reducing zooplanktivorous and benthivorous fish, thereby lowering trophic levels and ultimately improving water quality (SKOV et al., 2002).

\section{ACKNOWLEDGMENTS}

We thank Federico Bisonni and all the staff of the Piediluco Professional Fishermen's Cooperative the useful information provided and for field assistance. Sincere thanks are also due to the three anonymous reviewers for their helpful comments on earlier versions of the manuscript. 


\section{BIBLIOGRAPHY}

ADAMS C.E, TIPPETT R., 1991. Powan, Coregonus lavaretus (L.), ova predation by newly introduced ruffe, Gymnocephalus cernuus (L.), in Loch Lomond, Scotland. Aquacult. Fish. Manage., 22, 239-246.

ADAMS C.E., MAITLAND P.S., 1998. The ruffe population of Loch Lomond, Scotland: its introduction, population expansion, and interaction with native species. J. Great Lakes Res., 24, 249-262.

ANDERSON R.O., NEUMANN R.M., 1991. Length, Weight, and associated structural Indices. In MURPHY B.R. and WILLIS D.W. (eds.), Fisheries Techniques, 447-482. American Fisheries Society, Bethesda.

ARMSTRONG D.L., DEVRIES D.R., HARMAN, C., BAYNE, D.R., 1998. Examining similarities and differences between congeners: do larval gizzard shad and threadfin shad act as ecologically equivalent units? Trans. Am. Fish. Soc., 127, 1006-1020.

BAGENAL T.B., 1978. Fish production in fresh waters. Ed. Blackwell, Oxford.

BARAS E., KESTEMONT P., MELARD C., 2003. Effect of stocking density on the dynamics of cannibalism in sibling larvae of Perca fluviatilis under controlled conditions. Aquaculture, 219, 241-255.

BEECK P., TAUBER S., KIEL S., BORCHERDING J., 2002. 0+ perch predation on 0+ bream: a case study in a eutrophic gravel pit lake. Freshwater Biol., 47, 2359-2369.

BERGMAN E., 1988. Foraging abilities and niche breadth of two percids, Perca fluviatilis and Gymnocephalus cernua, under different environmental conditions. J. Anim. Ecol., 57, 443-453.

BERGMAN E., 1990. Effect of roach Rutilus rutilus on two percids, Perca fluviatilis and Gymnocephalus cernua: importance of species interactions for diet shift. Oikos, 57, 241-249.

BERGMAN E., 1991. Changes in abundance of two percids along a productivity gradient: relations to feeding strategies and competitive abilities. Can. J. Fish. Aquat. Sci., 48, 536-545.

BERGMAN E., GREENBERG L.A., 1994. Competition between a planktivore, a benthivore, and a species with ontogenetic diet shifts. Ecology, 75, 1233-1245.

CAROSI A., DÖRR M., GIOVINAZZO G., LORENZONI M., MEARELLI M., 1998. Gymnocephalus cernuus (Linnaeus, 1758) (Osteichthyes, Percidae) nel bacino del fiume Tevere. Quaderni ETP, 27, 103-108.

CHEN Y., JACKSON D.A., HARVEY H.H., 1992.) A comparison of von Bertalanffy and polynomial functions in modelling fish growth data. Can. J. Fish. Aquat. Sci., 49, 1228-1235.

CIOFFI F., GALLERANO F., 2000. Response of Lake Piediluco to the change of hydrodynamic conditions and nutrient load reductions. Ecol. Model., 135, 199-229.

CRAIG J.F., KIPLING C., 1983. Reproduction effort versus the environment, case histories of Windermere perch, Perca fluviatilis L. and pike, Esox lucius L. J. Fish Biol., 22, 713-727.

DE VRIES D. R., FRIE R. V., 1996. Determination of age and growth. In MURPHY B.R. and WILLIS D.W. (Eds.), Fisheries Techniques, 483-512. American Fisheries Society, Bethesda. 
DIETERICH A, BAUMGARTNER D, ECKMANN R., 2004. Competition for food between Eurasian perch (Perca fluviatilis L.) and ruffe (Gymnocephalus cernuus [L.]) over different substrate types. Ecol. Freshwat. Fish, 13, 236-244.

DÖRNER H., BERG S., JACOBSEN L., HÜLSMANN S., BROJERG M., WAGNER A., 2003. The feeding behaviour of large perch Perca fluviatilis (L.) in relation to food availability: a comparative study. Hydrobiologia, 506-509, 427-434.

ECKMANN R., 2004. Overwinter changes in mass and lipid content of Perca fluviatilis and Gymnocephalus cernuus. J. Fish Biol., 65, 1498-1511

FULLERTON A.H., LAMBERTI G.A., LODGE D.M., BERG M.B., 1998. Prey preferences of Eurasian ruffe and yellow perch: comparison of laboratory results with composition of Great Lakes benthos. J. Great Lakes Res., 24, 319-328.

FULLERTON A.H., LAMBERTI G.A., LODGE, D.M., GOETZ F.W., 2000. Potential for resource competition between Eurasian ruffe and yellow perch: growth and RNA responses in laboratory experiments. Trans. Am. Fish. Soc., 129, 1331-1339.

FULLERTON A.H., LAMBERTI G.A., 2006. A comparison of habitat use and habitatspecific feeding efficiency by Eurasian ruffe (Gymnocephalus cernuus) and yellow perch (Perca flavescens). Ecol. Freshwat. Fish, 15, 1-9.

GORETTI E., MARCUCCI C., DI VEROLI A., LA PORTA G., MEARELLI M., DI GIOVANNI M.V., 2004. II Lago di Piediluco: la comunità a macroinvertebrati del benthos profondo. Atti $65^{\circ}$ Congr. Naz. U.Z.I., 69-70.

GIOVINAZZO G., 1988. La pesca e l'accrescimento di Perca fluviatilis (L.). Riv. Idrobiol., 27 (2-3), 729-740.

HODGSON J.R., HE X., SCHINDLER D.E., KITCHELL J.F., 1997. Diet overlap in a piscivore community. Ecol. Freshwat. Fish, 6, 144-149.

HOLKER F., HAMMER C., 1994. Growth and food of ruffe Gymnocephalus cernuus (L.) in the Elbe Estuary. Archives of Fisheries and Marine Research, 42, 47-62.

HOLMGREN K., 2003. Omitted spawning in compensatory-growing perch. J. Fish Biol., $62,918-927$.

HOLMGREN K., APPELBERG M., 2001. Effects of environmental factors on size related growth efficiency of perch, Perca fluviatilis. Ecol. Freshwat. Fish, 10, 247-256.

HORPPILA J., RUUHIJARVI J., RASK M., KARPPINEN C., NYBERG K., OLIN M., 2000. Seasonal changes in the diets and relative abundances of perch and roach in the littoral and pelagic zones of a large lake. J. Fish Biol., 56, 51-72.

HORSTKOTTE J., STRECKER U., 2005. Trophic differentiation in the phylogenetically young Cyprinodon species flock (Cyprinodontidae, Teleostei) from Laguna Chichancanab (Mexico). Biol. J. Linn. Soc., 85, 125-134.

HOUTHUIJZEN R.P., BACKX J.J.G.M., BUIJSE A.D., 1993. Exceptionally rapid growth and early maturation of perch in a freshwater lake recently converted from an estuary. J. Fish Biol., 43, 320-324.

JANSSEN J., 1997. Comparison of response distance to prey via the lateral line in the ruffe and yellow perch. J. Fish Biol., 51, 921-930.

JENKINS R.E, BURKHEAD N.M., 1993. Freshwater fishes of Virginia. American Fisheries Society, Bethesda.

KANGUR K., KANGUR A., KANGUR P., 1999. A comparative study on the feeding of eel, Anguilla_anguilla (L.), bream, Abramis brama (L.) and ruffe, Gymnocephalus cernuus (L.) in Lake Vortsjarv, Estonia. Hydrobiologia, 408/409, 65-72. 
LAWRENCE S.G., MALLEY D.F., FINDLAY W.J., MACIVER M.A., DELBAERE L.L., 1987. Method for estimating dry weight of freshwater planktonic crustaceans from measures of length and shape. Can. J. Fish. Aquat. Sci., 44, 264-274.

LEVINS R., 1968. Evolution in changing environments: some theoretical exploitations. Princeton University Press, Princeton.

LORENZONI M., GIOVINAZZO G., MEARELLI M., NATALI, M., 1993. Growth and biology of perch (Perca fluviatilis L.) in Lake Trasimeno (Umbria, Italy). Pol. Arch. Hydrobiol., 40 (3-4) 313-328.

LORENZONI M., CORBOLI M., DÖRR A.J.M., GIOVINAZZO G., SELVI S., MEARELLI M., 2002. Diets of Micropterus salmoides Lac. and Esox lucius (L.) in Lake Trasimeno (Umbria, Italy) and their diets overlap. Bull. Fr. Pêche Piscicult., 365/366, 537-547.

LORENZONI M., PEDICILLO G., BOLOTTI G.M., CAROSI A., ANGELI V., BICCHI A., 2005. Monitoraggio ittico del lago di Piediluco. Università di Perugia, Perugia.

LORENZONI M., MEARELLI M., GHETTI L., 2006 Native and exotic fish species in the Tiber river watershed (umbria - italy) and their relationship to the longitudinal gradient. Bull. Fr. Pêche Piscicult., 382, 19-44.

MACEINA M.J., MURPHY B.R., 1988. Florida, Northern, and hybrid largemouth bass feeding characteristics in Aquilla Lake, Texas. Proc. Ann. Conf. Southeast Assoc. Fish Wildlife Ag., 42, 112-119.

MANN R.H.K., 1978. Observations on the biology of the perch, Perca fluviatilis L., in the River Stour, Dorset. Freshwater Biol., 8, 229-239.

MARSHALL S., ELLIOTT M., 1997. A comparison of univariate and multivariate numerical and graphical techniques for determining inter- and intraspecific feeding relationships in estuarine fish. J. Fish Biol., 51, 526-545.

MEARELLI M., 1988. Eutrofizzazione. Riv. Idrobiol., 27 (2-3), 651-661.

MEYER E., 1989. The relationship between body length parameters and dry mass in running water invertebrates. Arch. Hydrobiol., 117, 191-203.

MILLS E.L., LEACH J.H., CARLTON J.T., SECOR C.L., 1994. Exotic species and the integrity of the Great Lakes. BioScience, 44, 666-676.

MOHAN M.V., SANKARAN T.M., 1988. Two new indices for stomach content analysis of fishes. J. Fish Biol., 33, 289-292.

OGLE D.H., 1998. A Synopsis of the Biology and Life History of Ruffe. J. Great Lakes Res., 24 (2), 170-185.

OGLE D.H., SELGEBY J.H., NEWMAN R.M., HENRY M.G., 1995. Diet and feeding periodicity of ruffe in the St Louis River estuary, Lake Superior. Trans. Am. Fish. Soc., 124, 356-369.

OLIN M., RASK M., RUUHIJARVI J., KURKILAHTI M., ALA-OPAS P., YLONEN O., 2002. Fish community structure in mesotrophic and eutrophic lakes of southern Finland: the relative abundances of percids and cyprinids along a trophic gradient. J. Fish Biol., 60, 593-612.

PACE R., CAROSI A., CORBOLI M., PEDICILLO G., TRUSSO A., LORENZONI M., 2006. Accrescimento dell'acerina Gymnocephalus cernuus Linnaeus, 1758) nel Lago di Piediluco. Biologia Ambientale, 20 (1), 315-319.

PAUKERT C.P., WILLIS D.W., 2001. Comparison of exploited and unexploited yellow perch Perca flavescens (Mitchill) populations in Nebraska Sandhill lakes. Fisheries Manag. Ecol., 8, 533-542. 
PAULY D., MUNRO J.L., 1984. Once more on the comparison of growth in fish and invertebrates. ICLARM Fishbyte, 1(2), 21-22.

PEDERSEN J., 1999. Diet comparison between pelagic and demersal whiting in the North Sea. J. Fish Biol., 55, 1096-1113.

PERSSON L., GREENBERG L., 1990. Juvenile competitive bottlenecks: the perch (Perca fluviatilis) - roach (Rutilus rutilus) interaction. Ecology, 71, 44-56.

REZSU E., SPECZIAR A., 2006. Ontogenetic diet profiles and size-dependent diet partitioning of ruffe Gymnocephalus cernuus, perch Perca fluviatilis and pumpkinseed Lepomis gibbosus in Lake Balaton. Ecol. Freshwat. Fish, 15, 339-349.

RICCARDI R. 1955. II lago di Piediluco ed il suo bacino. Mem. Soc. Geogr. Ital., 22, 115195.

SCHAEFFER J.S., DIANA J.S., HAAS R.C., 2000. Effects of long-term changes in the benthic community on yellow perch in Saginaw Bay, Lake Huron. J. Great Lakes Res., 26, 340-351.

SCHLEUTER D., ECKMANN R., 2006. Competition between perch (Perca fluviatilis) and ruffe (Gymnocephalus cernuus): the advantage of turning night into day. Freshwat. Biol., 51, 287-297.

SCHLEUTER D., ECKMANN R., 2007. Generalist versus specialist: the performances of perch and ruffe in a lake of low productivity. Ecol. Freshwat. Fish, (On line early articles) 1-14.

SCHOENER T.W., 1970. Non-synchronous spatial overlap of lizards in patchy environments. Ecology, 51, 408-418.

SCOTT M.C., ANGERMEIER P.L., 1998. Resource use by two sympatric Black Basses in impounded and riverine sections of the New River, Virginia. N. Am. J. Fish. Manage., 18 (2), 221-235.

SHAFY M., MAITLAND P.S, 1971. The age and growth of perch (Perca fluviatilis_L.) in two Scottish lochs. J. Fish Biol., 3, 39-57.

SKOV C., PERROW M.R., BERG S. and SKOVGAARD H., 2002. Changes in the fish community and water quality during seven years of stocking piscivorous fish in a shallow lake. Freshwat. Biol., 47, 2388-2400.

SMOCK L.A., 1980. Relationships between body size and bio-mass of aquatic insects. J. Freshwat. Biol., 10, 375-381.

SVANBACK R., PERSSON L., 2004. Individual diet specialization, niche width and population dynamics: implications for trophic polymorphisms. J. Anim. Ecol., 73, 973-982.

THORPE J., 1977. Synopsis of biological data on the perch Perca fluviatilis Linneaus, 1758 and Perca flavescens (Mitchill,1814). FAO Fisheries Synopsis, 113, 1-138.

TYSON J.T., KNIGHT R.L., 2001. Response of yellow perch to changes in the benthic invertebrate community of Western Lake Erie. Trans. Am. Fish. Soc., 130, 766782.

VON BERTALANFFY L., 1938. A quantitative theory of organic growth. Hum. Biol., 10, 181-243.

WAHLI T., BURR S. E., PUGOVKIN D., MUELLER O., FREY J., 2005. Aeromonas sobria, a causative agent of disease in farmed perch, Perca fluviatilis L. J. Fish Dis., 28, 141-150. 
WALLACE R.K., 1981. An assessment of diet-overlap indexes. Trans. Am. Fish. Soc., 110, 72-76.

WERNER D.J., MITTLEBACH G.G., HALL D.J., 1981. The role of foraging profitability and experience in habitat use by bluegill sunfish. Ecology, 62, 116-125.

WILLIS D.W., GUY C.S., MURPHY B.R., 1991. Development and evaluation of a standard weight (Ws) equation for yellow perch. N. Am. J. Fish. Manage., 11, 374-380.

WOLFRAM-WAIS A., WOLFRAM G., AUER B., MIKSCHI E., HAIN A., 1999. Feeding habits of two introduced fish species (Lepomis gibbosus, Pseudorasbora parva) in Neusiedler See (Austria), with special reference to chironomid larvae (Diptera: Chironomidae). Hydrobiologia, 408-409, 123-129.

ZARET T.M., RAND A.S., 1971. Competition in tropical stream fishes: a support for the competitive exclusion principle. Ecology, 52, 336-342. 
